\title{
The role of calcium entry on the relaxation response of rho-kinase inhibitor in rabbit renal artery
}

\author{
Soner $\mathrm{BC}^{1}$, Murat $\mathrm{N}^{2}$, Guven $\mathrm{H}^{3}$, Gidener $\mathrm{S}^{3}$ \\ Necmettin Erbakan University, Meram Faculty of Medicine, Department of Pharmacology, Konya, Turkey. \\ burakcemsoner@gmail.com
}

\begin{abstract}
This study was performed to clarify the role of extracellular and intracellular $\mathrm{Ca}^{2+}$ on rho-kinase enzyme inhibition-induced relaxation in rabbit renal arteries. The response to rho-kinase inhibitor (Y-27632) was studied in isolated renal artery segments precontracted with phenylephrine in the presence of voltage-gated calcium channel blocker nifedipine and in the absence of intracellular or extracellular $\mathrm{Ca}^{2+}$. Cumulative addition of rho-kinase inhibitor Y-27632 $\left(10^{-8}-10^{-5} \mathrm{M}\right)$ produced a concentration-dependent relaxation in renal artery rings precontracted with phenylephrine. Preincubation with nifedipine $(1 \mu \mathrm{M})$ resulted in a significant increase in relaxation response to rho-kinase inhibitor Y-27632 compared with preincubation with DMSO; the solvent of nifedipine. The maximal relaxation to Y-27632 in renal arteries precontracted with phenylephrine was significantly increased in the Ca-free Krebs containing $100 \mu \mathrm{mol} / \mathrm{l}$ ethylene glycol tetraacetic acid (EGTA) but after depletion of intracellular stores with $20 \mathrm{mmol} / \mathrm{l}$ caffeine and $1 \mathrm{mmol} / \mathrm{IEGTA}$ in $\mathrm{Ca}^{2+}$ free $\mathrm{Krebs}$ there was no significant difference between the relaxation to Y-27632 from control response in $2.5 \mathrm{mmol} / \mathrm{/} \mathrm{Ca}{ }^{2+} \mathrm{Krebs}$ in the renal artery. These results suggest the involvement of extracellular $\mathrm{Ca}$ and L-type voltage-operated $\mathrm{Ca}^{2+}$ channels in phenylephrine-induced rho-kinase activation (Fig. 3, Ref. 20). Full Text in PDF www.elis.sk.

Key words: rho-kinase, calcium, rabbit, renal artery.
\end{abstract}

An achievement of vascular smooth muscle contraction, activation of subcellular system that mobilizes $\mathrm{Ca}^{2+}$ from extracellular and intracellular stores is required. Enrichment of free $\mathrm{Ca}^{2+}$ concentration increases the myosin light chain (MLC) kinase activity and MLC phosphorylation (1). It is also known that there is a second smooth muscle contractile mechanism that is defined as $\mathrm{Ca}^{2+}$ sensitization. $\mathrm{Ca}^{2+}$ sensitization of smooth muscle is composed of receptor stimulation which causes a decrease in MLC phosphatase activity mediated through the actions of protein kinase $\mathrm{C}$. Rho-kinase is involved in vascular smooth muscle contraction (2).

Previous studies demonstrated that after stimulation of RhoA with receptor agonists including angiotensin-II, endothelin-I, and phenylephrine, the induced rho-kinase activation increases the $\mathrm{Ca}^{2+}$ sensitivity which results in myosin light-chain phosphatase inhibition and contraction (3-5) However it was also shown that $\mathrm{Ca}^{2+}$-dependent rho-kinase activation also plays a role in smooth muscle contraction. Shabir et al have reported that Rho/Rho-kinase pathway targets $\mathrm{Ca}^{2+}$ entry through voltage-gated $\mathrm{Ca}^{2+}$ channels to enhance $\mathrm{Ca}^{2+}$ transients and contraction in rat and guinea-pig uretral smooth muscle (6).

There are distinct vasoconstriction mechanisms playing roles in renal artery vascular smooth muscle regulation (7). Rho-kinase

${ }^{1}$ Necmettin Erbakan University, Meram Faculty of Medicine, Department of Pharmacology, Konya, Turkey, and ${ }^{2}$ Dokuz Eylul University, Advanced Professional School of Health Sciences, Izmir, Turkey, and ${ }^{3}$ Dokuz Eylul University, Faculty of Medicine, Department of Pharmacology, Izmir, Turkey Address for correspondence: B.C. Soner, MD, Necmettin Erbakan University, Meram Faculty of Medicine, Department of Pharmacology, Konya, Turkey. Phone: +90332.2237921, Fax: +90332.2236181 enzyme activation involves agonist-induced vasocontriction in rat renal artery (8) by $\mathrm{Ca}^{2+}$ sensitization (9). In renal artery, the initial phase of phenylephrine-induced contraction is due to inositol triphosphate (IP3)-sensitive sarcoplasmic reticulum channels, while maintenance is supplied by L-type voltage-gated $\mathrm{Ca}^{2+}$ channels and receptor-operated $\mathrm{Ca}^{2+}$ channels (10). In various smooth muscles Rho/Rho-kinase inhibits phenylephrine-induced contraction (11, 12). Furthermore, the involvement of voltage-gated $\mathrm{Ca}^{2+}$ channels in rho-kinase enzyme inhibition in renal artery precontracted with phenylephrine is currently unknown.

Thus, this study was designed to determine the role of extracellular and intracellular $\mathrm{Ca}^{2+}$ on rho-kinase enzyme inhibitioninduced relaxation in isolated rabbit renal arteries.

\section{Methods}

\section{Animals and tissue preparation}

The study protocol was approved by Dokuz Eylul University Ethical Committee on Care and Use of Laboratory Animals. A total of 7 adult New Zealand White male rabbits weighing $2.5 \pm 0.5 \mathrm{~kg}$ (3 months old) were purchased from Ege University of Animal research center and used in the study. Rabbits were housed identically in individual cages in an air-conditioned room (temperature $23 \pm 2{ }^{\circ} \mathrm{C}, 12$-h light/dark cycle). All animals were fed ad libitum with standard plain diet and were allowed free access to water. Animals were killed by intravenous injection of thiopental anesthesia $(60 \mathrm{mg} / \mathrm{kg})$. The left renal artery was excised and cleaned of excess fat and connective tissue. The ring segments $(2-3 \mathrm{~mm}$ in length) were prepared and placed between stainless steel hooks and 
mounted in a 10-ml organ bath chamber in Krebs-Ringer buffer of composition (mM) as follows: $\mathrm{NaCl} 118, \mathrm{KCl} 4.7, \mathrm{CaCl}_{2} 2.5$, $\mathrm{MgSO}_{4} 1.2, \mathrm{KH}_{2} \mathrm{PO}_{4} 1.2, \mathrm{NaHCO}_{3} 25$, glucose 8.3, $\mathrm{pH} 7.4$, aerated with $95 \% \mathrm{O}_{2}$ and $5 \% \mathrm{CO}_{2}$. The rings were equilibrated for $1 \mathrm{~h}$, washed every 15 minutes at $+37^{\circ} \mathrm{C}$ with a resting tension of 1.5 $\mathrm{g}$. The force of contraction was measured with isometric tension transducer (MAY transducer), and isometric contractions were recorded continuously with an amplifier system (MP30 Biopac systems Inc., Santa Barbara California, U.S.A.) on a computer by using the Biopac computer program.

\section{Experimental protocols}

Acetylcholine (Ach)-induced $\left(10^{-6} \mathrm{M}\right)$ relaxation after $\mathrm{KCl}$ $(45 \mathrm{mM})$ precontraction was used to test the endothelial integrity. The depolarizing potassium solution had the same composition as the Krebs' buffer used except for $\mathrm{NaCl}$ that had been replaced with an equimolar amount of $\mathrm{KCl}$. The cumulative concentrationresponse curves were determined for phenylephrine $\left(10^{-6}-10^{-4} \mathrm{M}\right)$ in order to calculate $\mathrm{EC}_{80}$ value. Rho-kinase enzyme inhibitor Y27632-induced relaxation responses were expressed as percentage relaxation of constrictor response to phenylephrine.

Relaxation responses of rho-kinase inhibitor Y-27632 in rabbit renal artery: After precontraction of renal artery rings with $\mathrm{EC}_{80}$ of phenylephrine $\left(10^{-5} \mathrm{M}\right)$, rho-kinase inhibitor Y-27632 was added cumulatively $\left(10^{-8}-10^{-5} \mathrm{M}\right)$.

Relaxation responses of rho-kinase inhibitor Y-27632 in absence and presence of $\mathrm{Ca}^{2+}$ channel inhibitor nifedipine in rabbit renal artery. In group one, arterial rings were incubated with DMSO; as a vehicle of nifedipine; 15 min before phenylephrine contraction and cumulative relaxation responses to rho-kinase inhibitor, Y-27632 $\left(10^{-8}-10^{-5} \mathrm{M}\right)$ was determined. In group two, in order to study the role of voltage-dependent $\mathrm{Ca}^{2+}$ channel blockers on Y-27632-induced relaxations, arterial rings were incubated with $\mathrm{Ca}^{2+}$ channel blocker nifedipine $(1 \mu \mathrm{M})(13), 15$ min before the phenylephrine contraction.

Relaxation responses of rho-kinase inhibitor Y-27632 after depletion of intracellular $\mathrm{Ca}^{2+}$ stores in rabbit renal artery: The contribution of intracellular $\mathrm{Ca}^{2+}$ to relaxation induced by cumulative application of Y-27632 was assessed in renal arteries in $\mathrm{Ca}^{2+}$-free Krebs solution containing $100 \mu \mathrm{mol} / \mathrm{L}$ ethylene glycol tetraacetic acid (EGTA). The contribution of extracellular $\mathrm{Ca}^{2+}$ to relaxation response of Y-27632 was evaluated after depletion of intracellular $\mathrm{Ca}^{2+}$ stores. Depletion of intracellular $\mathrm{Ca}^{2+}$ stores was obtained by incubation of tissues with $20 \mathrm{mmol} / \mathrm{l}$ caffeine and $1 \mathrm{mmol} / 1$ EGTA in $\mathrm{Ca}^{2+}$ free Krebs for 10 minutes. Then bath solutions were replaced with normal Krebs solutions and Y-27632 was added cumulatively after precontraction with $\mathrm{EC}_{80}$ of phenylephrine (13).

Drugs

The following compound of nifedipine was dissolved in Dimethyl sulfoxide (DMSO). The other compounds as acetylcholine chloride, phenylephrine, caffeine, EGTA were purchased from Sigma Chemical Co. and dissolved in distilled water, while rho-kinase inhibitor Y-27632 (Calbiochem) was dissolved in cold water $\left(+4^{\circ} \mathrm{C}\right)$.

\section{Statistical analysis}

Data are expressed as mean $\pm \mathrm{SEM}$, with $\mathrm{n}$ referring to the number of strips used in each group. The sensitivity of artery to the cumulative relaxation response is presented as $\mathrm{pD}_{2}$ values, which are calculated as the negative log of a dose required to produce the half-maximal response. The results of cumulative concentration response curves were analyzed by using Student's t-test and one way analysis of variance (ANOVA) followed by Tukey's test. A level of $\mathrm{p}<0.05$ was considered statistically significant.

\section{Results}

Relaxation of renal artery with rho-kinase inhibitor Y-27632 precontracted with phenylephrine

Phenylephrine $\left(10^{-6}-10^{-4} \mathrm{M}\right)$ caused a dose-dependent contraction with an $\mathrm{EC}_{80}$ value $\left(10^{-5} \mathrm{M}\right)$ in isolated rabbit renal artery. Cumulative addition of $\mathrm{Y}-27632\left(10^{-8}-10^{-5} \mathrm{M}\right)$ produced a concentrationdependent relaxation in renal artery rings precontracted with $\mathrm{EC}_{80}$ dose of phenylephrine. The maximal relaxation responses and $\mathrm{pD}_{2}$ values for Y-27632 were $46.5 \pm 4.9 \%$ and $5.6 \pm 0.1 \%$, respectively.

Effect of $\mathrm{Ca}^{2+}$ channel blocker nifedipine on relaxation response to $Y-27632$

The effect of extracellular $\mathrm{Ca}^{2+}$ via voltage-gated L-type $\mathrm{Ca}^{2+}$ channels on response to Y-27632 was examined by the use of nifedipine. Preincubation with nifedipine $(1 \mu \mathrm{M})$ resulted in a significant increase in relaxation response to rho-kinase inhibitor Y-27632 (78.5 $\pm 2.1 \%)$, compared with the treatment with DMSO, solvent of nifedipine $(57.2 \pm 3.6 \%)$ and $2.5 \mathrm{mmol} / 1 \mathrm{Ca}^{2+} \mathrm{Krebs}$ $(46.5 \pm 4.9 \%)(\mathrm{p}=0.001)$ (Fig. 1).

Effects of extra- and intracellular sources of $\mathrm{Ca} 2+$ on relaxation response to $Y-27632$

The contributions of extra and intracellular sources of $\mathrm{Ca}^{2+}$ to relaxation response induced by Y-27632 are shown in Figure 2. Relaxation response to Y-27632 in $2.5 \mathrm{mmol} / 1 \mathrm{Ca}^{2+} \mathrm{Krebs}$ was used as control in renal artery. The maximal relaxation to Y-27632 $(46.5 \pm 4.9 \%)$ in renal arteries precontracted with phenylephrine

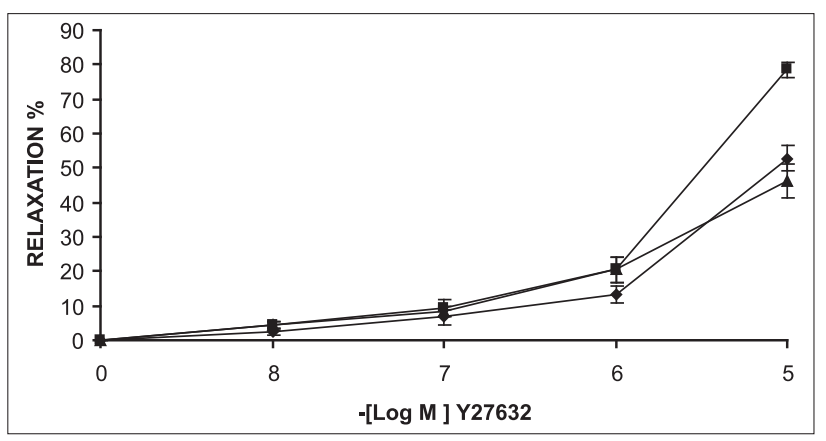

Fig. 1. Rho-kinase inhibitor, Y-27632-induced relaxation in rabbit renal artery in presence of $\mathrm{Ca}$ channel blocker of nifedipine (n: $6, \mathbf{m}$ ), DMSO (n: 7, ) (solvent of nifedipine) and in $2.5 \mathrm{mmol} / \mathrm{LCa}$ Krebs (n: $8, \bullet)$. Data are mean \pm SEM and are expressed as percentage of maximal contraction to phenylephrine. * $\mathbf{p}<0.001$. 


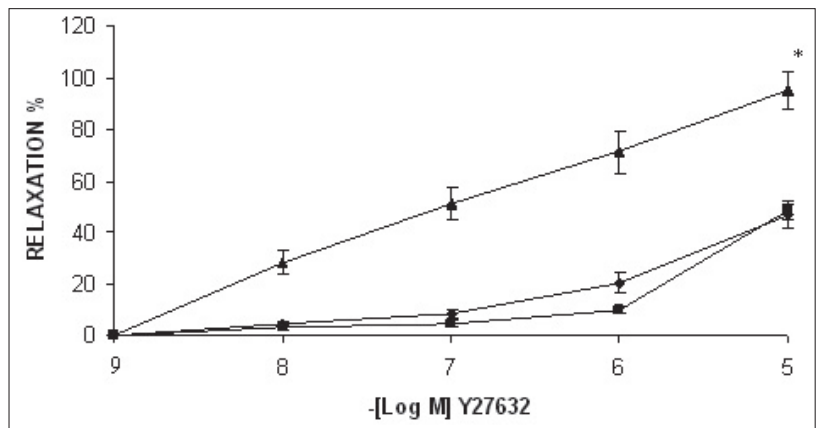

Fig. 2. Cumulative dose response curve for Y-27632 in $2.5 \mathrm{mmol} / \mathrm{LCa}$

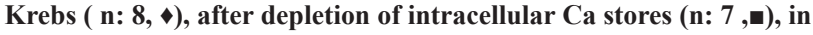
$\mathrm{Ca}$ free Krebs (n: $6 \Delta$ ) in rabbit renal artery. Data are expressed as mean \pm SEM. $p<0.0001$.

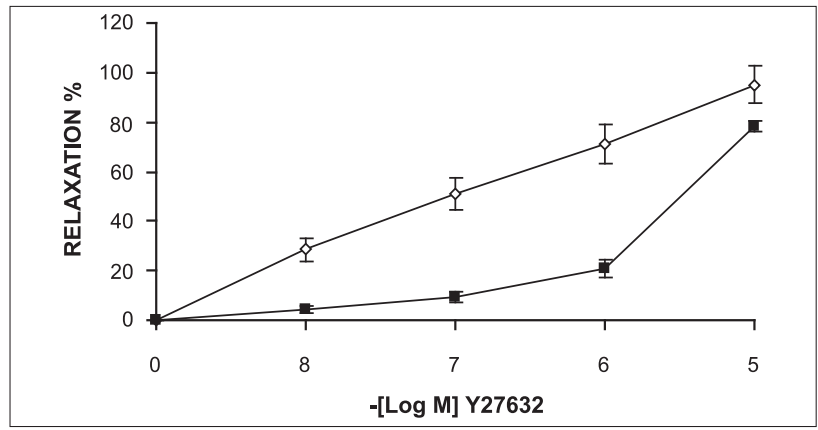

Fig. 3. Cumulative dose response curve for Y-27632 in presence of nifedipine (n: 6, ) and in $\mathrm{Ca}$ free Krebs (n: 6, $\square)$, in rabbit renal artery. Data are expressed as mean \pm SEM. $p>0.05$.

was significantly increased in $\mathrm{Ca}^{2+}$-free Krebs containing 100 $\mu \mathrm{mol} / 1$ EGTA $(95.1 \pm 7.4 \%)$ but after depletion of intracellular stores with $20 \mathrm{mmol} / 1$ caffeine and $1 \mathrm{mmol} / 1$ EGTA in $\mathrm{Ca}^{2+}$ free Krebs $(48.7 \pm 3.9 \%)$ there was no significant difference between the relaxation to Y-27632 from control response in $2.5 \mathrm{mmol} / 1$ $\mathrm{Ca}^{2+}$ Krebs in renal artery (Fig. 2). The $\mathrm{pD}_{2}$ values of $\mathrm{Y}-27632$ were $5.6 \pm 0.1$ in $2.5 \mathrm{mmol} / 1 \mathrm{Ca}^{2+} \mathrm{Krebs}, 4.4 \pm 0.3$ in $\mathrm{Ca}^{2+}$-free Krebs containing $100 \mu \mathrm{mol} / 1 \mathrm{EGTA}$ and $20 \mathrm{mmol} / \mathrm{l}$ caffeine and $6.5 \pm 0.2$ in $1 \mathrm{mmol} / 1 \mathrm{EGTA}$ in $\mathrm{Ca}^{2+}$ free Krebs, and significantly different in all groups $(\mathrm{p}<0.0001)$

As shown in the Figure 3, the maximal relaxation response of Y-27632 in presence of $1 \mathrm{mmol} / \mathrm{l}$ EGTA in $\mathrm{Ca}^{2+}$ free Krebs was higher than when voltage-gated Ca entry was blocked with nifedipine. Although a difference has been observed between groups it was not significant ( $\mathrm{p}=0.056$ ) (Fig. 3). Also $\mathrm{pD}_{2}$ values of Y-27632 were significantly higher in the presence of $1 \mathrm{mmol} / 1 \mathrm{EGTA}$ in $\mathrm{Ca}^{2+}$ free Krebs $(6.49 \pm 0.2)$ than in that of nifedipine $(4.49 \pm 0.2)(\mathrm{p} \leq 0.001)$.

\section{Discussion}

The present results indicate that $\mathrm{Ca}^{2+}$-dependent mechanisms have a role in rho-kinase inhibitor-induced relaxation responses in rabbit renal artery precontracted with phenylephrine.

Rho-kinase inhibitor causes relaxation in vascular and other smooth muscles precontracted with different constrictors. It was reported that the rho-kinase inhibitor caused $55 \%$ relaxation responses in the mouse anococcygeus muscle while $90 \%$ in rabbit aorta (14). Also, Ark et al reported more than $75 \%$ relaxation response of rho-kinase inhibitor Y-27632 in rat renal artery precontracted with ouabain (15). In our study we showed that rho-kinase inhibitor diminished $46 \%$ of contraction induced by phenylephrine. According to these reports we suggested that activation of Rho/Rho-kinase pathway with different agonists in distinct smooth muscles caused different rates of relaxation responses.

Until now it has been known that a Rho/ Rho-kinase pathwayinduced contraction is mediated by $\mathrm{Ca}^{2+}$ sensitization. However, there are some studies that revealed the relationship between $\mathrm{Ca}$ mobilization and Rho/rho-kinase pathway in different smooth muscles. A recent study has reported that Rho/Rho-kinase pathway affects agonist-induced $\mathrm{Ca}^{2+}$ mobilization. In this study it is well established that receptor-operated $\mathrm{Ca}^{2+}$ influx is inhibited by rhokinase inhibition in tracheal smooth muscle (16). In another study, Shabir et al have shown that the rho-kinase activity without agonists modulates the myogenic contraction in both $\mathrm{Ca}^{2+}$-dependent and independent mechanisms in ureteral smooth muscle (6). In another perspective it was reported that the involvement of $\mathrm{Ca}^{2+}$ entry induces the rho-kinase activation (17).

It has been shown that agonist-induced activation of Rho/Rhokinase pathway causes contraction via $\mathrm{Ca}^{2+}$ sensitization in renal artery (18). It is also known that the increase in $\mathrm{Ca}^{2+}$ evoked by phenylephrine in renal artery originates from inositol triphosphate due to the release of $\mathrm{Ca}^{2+}$ from sarcoplasmic reticulum, capacitative $\mathrm{Ca}^{2+}$ entry intracellular store (19) and entry of $\mathrm{Ca}^{2+}$ through voltage-dependent $\mathrm{Ca}^{2+}$ channels (20). In our study we hypothesized the role of $\mathrm{Ca}^{2+}$ mobilization in Rho/Rho-kinase-induced contraction. According to our results, Y-27632 inhibited the contraction induced by phenylephrine in a concentration-dependent manner in an absence of extracellular $\mathrm{Ca}^{2+}$. Also inhibiting the $\mathrm{Ca}^{2+}$ influx through voltage-gated $\mathrm{Ca}^{2+}$ channel attenuated the rho-kinase inhibition-induced relaxation. Our data are consistent with $\mathrm{Ca}^{2+}$ influx through voltage-operated channels affecting the rho-kinase activation in vascular smooth muscle (17). However, there is an increase in relaxation response induced by rho-kinase inhibitor in the presence of total withdrawal of $\mathrm{Ca}^{2+}$ compared to inhibition of $\mathrm{Ca}^{2+}$ entry through L-type $\mathrm{Ca}^{2+}$ channels. Nevertheless, the increase is not clearly significant at all concentrations (Fig 3 ). These results indicate that in addition to $\mathrm{Ca}^{2+}$ influx through voltage-operated channels, other $\mathrm{Ca}^{2+}$ influx pathways may also affect the inhibition of rho-kinase enzyme in renal artery. On the other hand, similarly to Shabir et al data, our results show that the depletion of sarcoplasmic reticulum $\mathrm{Ca}^{2+}$ stores did not contribute to the effects of rho-kinase inhibition (16).

In conclusion, we have determined the involvement of extracellular $\mathrm{Ca}^{2+}$ and L- type voltage-operated $\mathrm{Ca}^{2+}$ channels in phenylephrine-induced Rho-kinase activation that in addition to its role in $\mathrm{Ca}^{2+}$ sensitization of the contractile proteins in renal artery there is a relationship between $\mathrm{Ca}^{2+}$ mobilization and rhokinase activation. The distinct role of Rho/Rho-kinase pathways in phenylephrine-induced contraction in renal artery may be attributable to a different $\mathrm{Ca}^{2+}$ entry in renal artery smooth muscle. 
Therefore, a better understanding of intracellular mechanisms of contraction and relaxation of renal artery is of fundamental interest to improve the urological treatment.

\section{References}

1. Fukata Y, Amano M, Kaibuchi K. Rho-Rho-kinase pathway in smooth muscle contraction and cytoskeletal reorganization of non-muscle cells. Trends Pharmacol Sci 2001; 22 (1): 32-39.

2. Urban NH, Berg KM, Ratz PH. $\mathrm{K}^{+}$depolarization induces RhoA kinase translocation to caveolae and $\mathrm{Ca}^{2+}$ sensitization of arterial muscle. Am J Physiol Cell Physiol 2003; 285 (6): 1377-1385.

3. Ghisdal P, Vanderberg G, Morel N. Rho-dependent kinase is involved in agonist aactivated calcium entry in rat arteries. J Physiol 2003; 551 (3): 855-867.

4. Chitaley K, Webb RC. Nitric oxide induces dilation of rat aorta via inhibition rho-kinase signaling. Hypertension 2002; 39: 438-442.

5. Wettschureck N, Offermanns $S$. Rho/Rho-kinase mediated signaling in physiology and pathophysiology. J Mol Med 2002; 80 (10): 629-638.

6. Shabir S, Borisova L, Wray S, Burdyga T. Rho-kinase inhibition and electromechanical coupling in rat and guinea-pig ureter smooth muscle: $\mathrm{Ca}^{2+}$-dependent and -independent mechanisms. J Physiol 2004; 560 (Pt 3): 839-855.

7. Taniguchi J, Honda H, Shibusawa Y, Iwata T, Notoya Y. Alteration in endothelial function and modulation by treatment with pioglitazone in rabbit renal artery from short-term hypercholesterolemia. Vascul Pharmacol 2005; 43 (1): 47-55.

8. Bauer J, Parekh N. Variations in cell signaling pathways for different vasoconstrictor agonists in renal circulation of the rat. Kidney Int 2003; 63 (6): 2178-2186.

9. Cavarape A, Endlich N, Assaloni R, Bartoli E, Steinhausen M, Parekh N, Endlich K. Rho-kinase inhibition blunts renal vasoconstriction induced by distinct signaling pathways in vivo. Am Soc Nephrol 2003; 14 (1): 37-45.

10. Lee CH, Poburko D, Sahota P, Sandhu J, Ruehlmann DO, van Breemen $\mathbf{C}$. The mechanism of phenylephrine-mediated $[\mathrm{Ca}(2+)](\mathrm{i})$ oscillations underlying tonic contraction in the rabbit inferior vena cava. $\mathrm{J}$ Physiol 2001; 534 (Pt 3): 641-650.
11. Demir O, Murat N, Aslan G, Gidener S, Esen AA. Effect of doxazosin with and without rho-kinase inhibitor on human corpus cavernosum smooth muscle in the presence of bladder outlet obstruction. J Urol 2006; 175 (6): 2345-2349.

12. Budzyn K, Paull M, Marley PD, Sobey CG. Segmental differences in the roles of rho-kinase and protein kinase $\mathrm{C}$ in mediating vasoconstriction. J Pharmacol Exp Ther 2006; 317 (2): 791-796.

13. Callera GE, Bendhack LM. Mechanisms underlying the contractile response to endothelin-1 in the rat renal artery. Pharmacology 2003; 68 (3): 131-139.

14. Ayman S, Wallace P, Wayman CP, Gibson A, McFadzean I. Receptor- independent activation of Rho-kinase-mediated calcium sensitisation in smooth muscle. Br J Pharmacol 2003; 39 (8): 1532-1538.

15. Ark M, Kubat H, Beydagi H, Ergenoglu T, Songu-Mize E. Involvement of rho kinase in the ouabain-induced contractions of the rat renal arteries. Biochem Biophys Res Commun 2006; 340 (2): 417-421.

16. Ito S, Kume H, Yamaki K, Katoh H, Honjo H, Kodama I, Hayashi H. Regulation of capacitative and noncapacitative receptor-operated $\mathrm{Ca}^{2+}$ entry by rho-kinase in tracheal smooth muscle. Am J Respir Cell Mol Biol 2002; 26 (4): 491-498.

17. Sakurada S, Takuwa N, Sugimoto N, Wang Y, Seto M, Sasaki Y, Takuwa Y. $\mathrm{Ca}^{2+}$-dependent activation of Rho and Rho kinase in membrane depolarization-induced and receptor stimulation-induced vascular smooth muscle contraction. Circ Res 2003; 93 (6): 548-556.

18. Nakamura A, Hayashi K, Ozawa Y, Fujiwara K, Okubo K, Kanda T, Wakino S, Saruta T. Vessel-and vasoconstrictor-dependent role of rho/ rho-kinase in renal vascular tone. J Vasc Res 2003; 40: 244-251

19. Utz J, Eckert R, Trautwein W. Changes of intracellular calcium concentrations by phenylephrine in renal arterial smooth muscle cells. Pflugers Arch 1999; 438 (6): 725-731.

20. Karsten AJ, Eckert RE. Involvement of signal transducing GTPbinding proteins in renal artery alpha 1-adrenoceptor mediated smooth muscle contraction. BJU Int 2004; 93 (4): 622-625.

Received November 30, 2011. Accepted January 18, 2013. 